\title{
Using e-Portfolio to Develop IMT Skills among Trainee Teachers in a Malaysian University
}

\author{
Azidah Abu Ziden ${ }^{1, *}$, Muhammad Faizal Abdul Rahman ${ }^{2}$, Fadzilah Amzah ${ }^{1}$, Adu Emmanuel Ifedayo ${ }^{1}$ \\ ${ }^{1}$ School of Educational Studies, Universiti Sains Malaysia, Malaysia \\ ${ }^{2}$ Department of IT, Hospital Seberang Jaya, Malaysia
}

Received May 28, 2020; Revised August 7, 2020; Accepted August 25, 2020

\section{Cite This Paper in the following Citation Styles}

(a): [1] Azidah Abu Ziden, Muhammad Faizal Abdul Rahman, Fadzilah Amzah, Adu Emmanuel Ifedayo , "Using e-Portfolio to Develop IMT Skills among Trainee Teachers in a Malaysian University," Universal Journal of Educational Research, Vol. 8, No. 10, pp. 4470-4477, 2020. DOI: 10.13189/ujer.2020.081014.

(b): Azidah Abu Ziden, Muhammad Faizal Abdul Rahman, Fadzilah Amzah, Adu Emmanuel Ifedayo (2020). Using e-Portfolio to Develop IMT Skills among Trainee Teachers in a Malaysian University. Universal Journal of Educational Research, 8(10), 4470-4477. DOI: 10.13189/ujer.2020.081014.

Copyright $\odot 2020$ by authors, all rights reserved. Authors agree that this article remains permanently open access under the terms of the Creative Commons Attribution License 4.0 International License

\begin{abstract}
Trainee teachers in Malaysia are encountering new development in the open market that requires skills of the $21^{\text {st }}$ century. This study thus investigated the skills of information, media and technology (IMT) among trainee teachers at a Malaysian university by exploring e-portfolio at Mahara@USM to improve IMT skills in the $21^{\text {st }}$ century. This study involved a quantitative method, which utilised questionnaires as a research instrument for data gathering activities. Also, a total of 265 trainee teachers were involved in this research for a seven-week intervention study. Using both descriptive and inferential statistics, this research data was analysed. In addition, the inferential statistics introduced in this study data analysis are t-test and ANOVA. These research findings have shown that trainee teachers possess the necessary IMT skills to prepare an e-portfolio. However, the findings of this research have shown that there is a significant difference in media literacy skills among trainee teachers from various majors. Trainee teachers and majors had no sign of information literacy skills in this enquiry. Additionally, there were no signs of information and communication technology skills among the trainee teachers and majors. This study contributes to the existing literature on $21^{\text {st }}$ century IMT skills for trainee teachers. This research fills the gap that exists due to global changes in IMT capabilities in the need for a pedagogical paradigm shift.
\end{abstract}

Keywords $21^{\text {st }}$ Century Skills, IMT Skills, e-Portfolio, Information Literacy, Media Literacy, Information and
Communication Technology (ICT), Trainee Teachers

\section{Introduction}

The preparation of a skilful and competent workforce is essential for educational development in Malaysia. Thus, to produce a futuristic workforce in higher educational system, there must be adequate cognizance of agents required in providing human resources for impending purposes [1]. The teachers must possess $21^{\text {st }}$ century skills to be considered as being ready for Malaysian educational system in this $4^{\text {th }}$ industrial revolution era. Janet, Kimberly \& Ken[2] stressed that by introducing skills and professions of the $21^{\text {st }}$ century into the technical education system, students must be educated for professions. Trainee teachers need to have skills valued for a creative and inventive society. The IMT skill is considered as one of the three essential issues in this $21^{\text {st }}$ century that was proposed in partnership for $21^{\text {st }}$ century skills (P21) framework [3]. The $21^{\text {st }}$ century skill is defined as a student's ability to succeed in learning, work and life in this present society [4].

The theory proposed in the Partnership for $21^{\text {st }}$ Century framework provides details of the IMT skills specific requirements. The IMT skill was listed as one of the core skills in the National graduate employment roadmap for 2012-2017 in Malaysia. The information, media and 
technology skills involve three components, which are information literacy, media literacy with information, and communication technology skills. A country's citizens must be able to demonstrate a variety of practical skills relating to information, media and technology that will be useful in this $21^{\text {st }}$ century [3]. The P21 framework is one of the elements addressing student outcomes in this $21^{\text {st }}$ century. In addition, the mastery of technology skills such as information literacy, media literacy and ICT literacy [5], digital age literacy [6], digital literacy skills [7] and so on demand learners to demonstrate various practical skills related to information, media. and technology.

In addition, these are crucial attributes in the $21^{\text {st }}$ century, with its technology and media-sufficient environment characterized by access to overwhelming amounts of information, radical growth of technological tools and the ability to collaborate and make individual contributions to an exceptional level [3]. This study considered technology proficiency in the capacity of pre-service teachers in a university in Malaysia towards using IMT skills to produce e-Portfolio (see Figure 1). This entails learners' abilities to access media and handle ICT tools accurately in the e-Portfolio. The digital media and ICT literacy require student's basic knowledge of ethical issues surrounding digital, media, and ICT use.

The global economy is highly impacted by skills in educational institutions. Hence, educational systems are moving towards $21^{\text {st }}$ century skills for student's development to survive in this era. Also, teachers are the crucial agents that assist students in developing the IMT skills. However, the IMT skills of teachers or trainee teachers have not been adequately addressed through research. Hence, this study explores the use of e-Portfolio to address trainee teacher' IMT skills preparedness for different teaching and learning scenarios.

\section{1. e-Portfolio}

Pitts \& Lehner-Quam [8] recommended e-Portfolio practice as requiring additional research in various contexts. The e-Portfolio is a digital collection of artwork, artefact, paperwork and accomplishment of an individual, group, community, or institution [9]. For instance, Douglas [10] suggested that e-Portfolio reinforces the learning process, embraces a user-centric approach and prompts student's responsibility in education. Also, Douglas [10] further suggested that e-Portfolio is an integral part of Learning Management Systems (LMS) that allow students to obtain constructive feedback from peers and showcase achievements to multiple audiences. The e-Portfolio is a platform that students utilise to compile, organise and formulate digital presence across various types of media [11]. The e-Portfolio is widely utilised in higher education to help students develop critical thinking and problem-solving skills as well as to prepare learners for assessment, learning and employment [12]. The e-Portfolio has been considered as very germane towards students' learning. However, the Malaysian higher education system has not adequately addressed the e-Portfolio as one of the alternative assessment methods for teacher education.
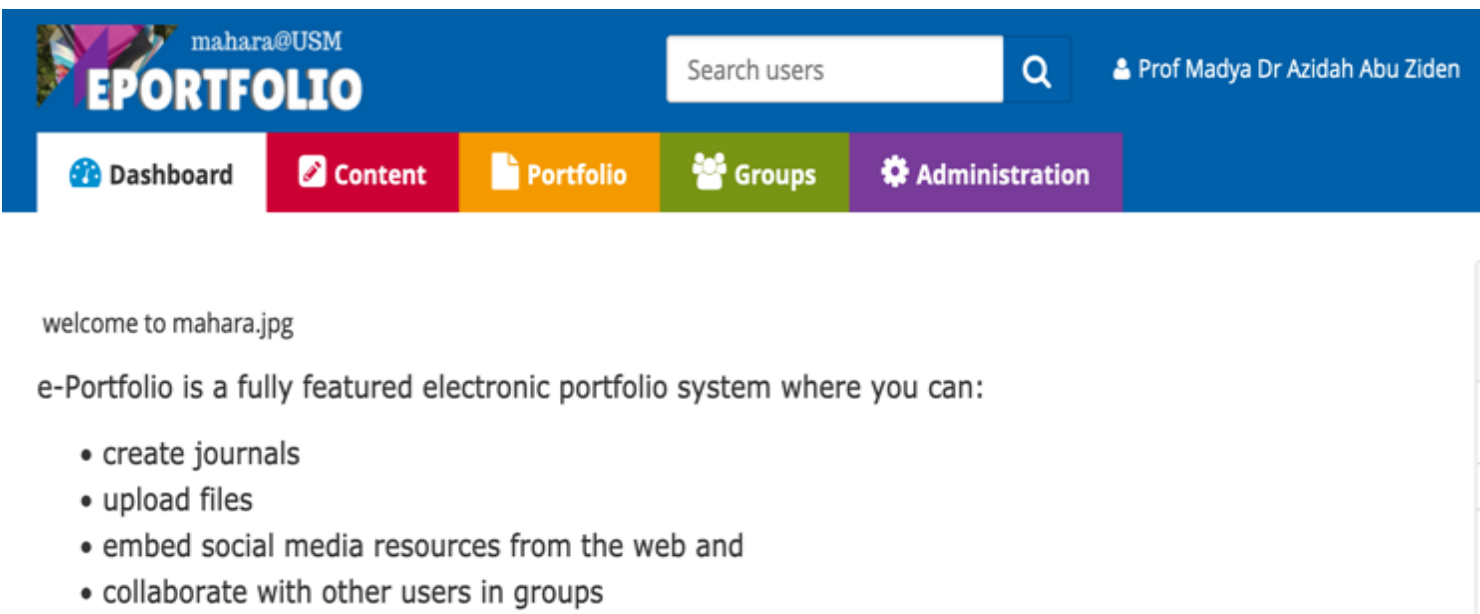

Figure 1. Mahara@USM platform 


\section{2. e-Portfolio for Trainee Teachers}

Some of the challenges affecting trainee teachers in this $21^{\text {st }}$ century are related to unemployment. Older Malaysian generation used to encourage youths to become teachers due to the job opportunities imbued in teacher education. Trainee teachers nowadays remain unemployed after graduation because of increasing unemployment. Hence, trainee teachers must possess adequate skills to secure jobs in this $21^{\text {st }}$ century. IMT skills are necessary for graduates and must be integrated into the higher education taught modules. The IMT skills are not mandatory in the curriculum. However, IMT skills are crucial for students in securing employment in multiple sectors [13]. Available research evidence regarding unemployment issues revealed that educational institutions must embed skills in curricula activities to improve future workforce [14][15][16].

\subsection{Information Media and Technology (IMT) Skills}

The $21^{\text {st }}$ century skills are crucial to many educational systems. Also, previous studies highlighted the importance of the $21^{\text {st }}$ century skills towards nurturing graduates for employment after graduation [17][2]. The Malaysian Ministry of Education plays an important part in preparing students, educators, schools and higher education institutions for higher level productivity [18]. The partnership for $21^{\text {st }}$ century skills [3] proposed a framework that illustrates the skills, knowledge and expertise for students to be competitive and excel in life. In particular, to excel in today's society, the students must learn vital skills in critical thought, problem-solving, teamwork, and collaboration.

The core issues of this framework are topics mastery, themes of the $21^{\text {st }}$ century, learning, $21^{\text {st }}$ century themes, learning, innovation, life, IMT and career skills. The work of Osman, Soh \& Arsad [19] referred to as Malaysian $21^{\text {st }}$ century skills instrument (M-21CSI) was developed to investigate whether the skills of the $21^{\text {st }}$ century are applicable to teaching and learning activities. The instrument was introduced to quantify the Malaysian skills of the $21^{\text {st }}$ century and consisted of modern age literacy, creative thought, strong leadership abilities, high competitiveness, and moral values. The skills of the $21^{\text {st }}$ century are known to be the basic skills required for thousands of learners to remain up to date in this new environment. Past empirical data has demonstrated that the teaching and learning capabilities of the $21^{\text {st }}$ century are suitable in educational institutions. Also, prior researches have focused on ICT with regards to $21^{\text {st }}$ century skills [20] [7] [21].

In the light of globalization, much attention has been given to this teaching of ICT and the incorporation of technology in instructional practices. The students must go beyond learning core subjects and prepare to acquire $21^{\text {st }}$ century skills in tertiary educational systems [22]. In this $21^{\text {st }}$ century, however, the incorporation of technology to promote the learning of IMT skills by students remains moderate. Previous studies revealed that teachers often lack the knowledge to successfully integrate technologies for educational activities [23]. Littrell, Zagumny \& Zagumny [24] research showed that there is limited utilisation of available technologies in schools. Technology and ICT methods are therefore not fully incorporated into classroom practices. Teachers must adopt emerging technology to make teaching and learning practices better [25]. Saveedra[26] claims that appropriate preparation is essential to the ability and skills of teachers to use computers for educational activities. However, professional development is fragmented without any focus on $21^{\text {st }}$ century skills [27].

This research focused on $21^{\text {st }}$ century IMT skills as an ability to be incorporated into the learning cycle of trainee teachers. This is to help graduates survive the workforce in Malaysia in the $21^{\text {st }}$ century. The skills of the $21^{\text {st }}$ century are vital to the success of students. Global competitiveness, increased technical exposure, digital knowledge and resources have enhanced the value of skills in the $21^{\text {st }}$ century [4]. Employees with inadequate skills in the $21^{\text {st }}$ century are now seen as burdening employers [4]. The skills of the $21^{\text {st }}$ century create new contextual capabilities that are useful for the future industrial revolution. This study provides insight into IMT skills and addresses open market issues for new teachers in Malaysia.

\section{Research Methods and Design}

This study involves a cross-sectional quantitative method to investigate the IMT skills in Malaysia. This research respondents were trainee teachers from a Malaysian higher educational system. The purposive sampling technique was utilised in selecting $3^{\text {rd }}$ and $4^{\text {th }}$ year trainee teachers in a Malaysian higher educational system. Also, a total of 265 trainee teachers were involved in this study. The research instrument used was a researcher designed to adapt and implement issues relevant to IMT skills. The research tool was administered to allow respondents to provide answers on the variables being investigated, such as media literacy, information literacy and communication technology skills. Items of the research instrument have been adapted and adopted from a number of sources closely related to IMT in the $21^{\text {st }}$ century. The research instrument was made up of three sections and five sub-sections to address the elements of $21^{\text {st }}$ century IMT skills for students.

The trainee teachers were given an e-Portfolio project in this research. Also, the trainee teachers had a seven-week ultimatum to prepare e-Portfolios in Mahara@USM. The trainee teachers were instructed on various aspects of e-Portfolio such as micro-teaching videos, infographics, curriculum vitae, learning experiences and other technology-based activities. The Mahara@USM features 
include file repository, media artefacts, and compilation activities. At the end of the semester, all e-Portfolio was marked and evaluated by lecturers. In addition, the ethical issues in educational research were duly observed during data gathering activities. A pilot study was conducted and its result showed that this research instrument has high reliability to be utilised for data gathering. The research instrument was administered to respondents after six weeks of e-Portfolio task.

\subsection{Data Analysis}

Data analysis was conducted using the IBM SPSS version 21 statistical software. The module offered to trainee teachers was an elective course at the institution. The trainee teachers came from different majors such as teaching English to speakers of other languages (TESOL), arts, and sciences. The total respondents involved in this study were 178 (67.2\%) female and 87 (32.8\%), male. The main variables in this study are IMT skills possessed by trainee teachers in a Malaysian University. The IMT skills are made up of three main elements and each element has a sub-element. For instance, media literacy has sub-element like analyses and the creation of media products. Also, information literacy consists of access, evaluation, information use, and management. The information and communication technology consists of technology application sub-element. Table 1 shows the calculated mean score of elements for each IMT skill. The mean score for all five sub-elements is varied between the range of 4.01 and 4.41. The highest mean score is the sub-element of media literacy skills, namely analyse media $(\mathrm{M}=4.41$, $\mathrm{SD}=.62)$. The lowest mean score is the sub-element called create media products $(\mathrm{M}=4.01, \mathrm{SD}=.55)$

\subsection{Comparison between the Media Literacy Skills among Trainee Teachers for Different Majors}

H01a: There is no significant difference between the media literacy skills students possess in the creation of e-Portfolio for various majors

A one-way between-group analysis of variance (one-way ANOVA) was conducted to explore the trainee teachers' majors on media literacy skills. The respondents from this study were divided into three groups according to majors such as TESOL, sciences, and arts. Levene's test for homogeneity of variance was conducted and the significant value was $p=.967>0.05$ as shown in Table 2 . Thus, the homogeneity of variance assumption is not violated. The null hypothesis for the homogeneity assumption is retained and it reveals that there is no significant difference between the group's variances, as shown in Table 3.

Table 1. Mean value and standard deviation using e-portfolio for IMT skills elements

\begin{tabular}{|c|c|c|c|c|c|c|c|c|}
\hline \multirow{2}{*}{ IMT Skill Elements } & Sub-Elements & $\mathrm{N}$ & Minimum & Maximum & Mean & $\begin{array}{c}\text { Std. } \\
\text { Deviation }\end{array}$ & \multicolumn{2}{|c|}{ Skewness } \\
\cline { 2 - 9 } & Statistics & Statistics & Statistics & Statistics & Statistics & Statistics & Std. Error \\
\hline \multirow{2}{*}{ Media Literacy Skills } & Analyse Media & 265 & 1.00 & 6.00 & 4.41 & .62 & .080 & .085 \\
\cline { 2 - 11 } & Create Media Products & 265 & 1.86 & 5.87 & 4.01 & .55 & .271 & .085 \\
\hline \multirow{2}{*}{$\begin{array}{c}\text { Information Literacy } \\
\text { Skills }\end{array}$} & $\begin{array}{c}\text { Access and Evaluate } \\
\text { Information }\end{array}$ & 265 & 2.00 & 6.00 & 4.27 & .63 & .297 & .085 \\
\cline { 2 - 10 } & $\begin{array}{c}\text { Use and Manage } \\
\text { Information }\end{array}$ & 265 & 2.32 & 6.00 & 4.41 & .61 & .378 & .085 \\
\hline $\begin{array}{c}\text { Information and } \\
\text { Communication } \\
\text { Technology Skills }\end{array}$ & $\begin{array}{c}\text { Apply Technology } \\
\text { Effectively }\end{array}$ & 265 & 1.88 & 6.00 & 4.25 & .60 & .380 & .085 \\
\hline
\end{tabular}

Table 2. Descriptive Table for Media Literacy skills

\begin{tabular}{|c|c|c|c|c|c|c|c|c|}
\hline & \multirow{2}{*}{$\mathrm{N}$} & \multirow{2}{*}{ Mean } & \multirow{2}{*}{ Std. Deviation } & \multirow{2}{*}{ Std. Error } & \multicolumn{2}{|c|}{$\begin{array}{l}\text { 95\% Confidence Interval for } \\
\text { Mean }\end{array}$} & \multirow{2}{*}{ Min } & \multirow{2}{*}{ Max } \\
\hline & & & & & $\begin{array}{l}\text { Lower } \\
\text { Boundary }\end{array}$ & $\begin{array}{l}\text { Upper } \\
\text { Boundary }\end{array}$ & & \\
\hline TESOL & 78 & 4.3294 & .51218 & .03491 & 4.2605 & 4.3895 & 3.12 & 5.71 \\
\hline ARTS & 144 & 4.2199 & .53342 & .02390 & 4.1618 & 4.2481 & 1.94 & 5.94 \\
\hline SCIENCE & 43 & 4.1627 & .54229 & .05011 & 4.0608 & 4.2618 & 3.12 & 5.71 \\
\hline Total & 265 & 4.2242 & .53184 & .01856 & 4.1875 & 4.2703 & 1.94 & 5.94 \\
\hline
\end{tabular}


Table 4. ANOVA Table for Media Literacy

\begin{tabular}{|c|c|c|c|c|c|}
\hline & $\begin{array}{c}\text { Sum of } \\
\text { Squares }\end{array}$ & df & $\begin{array}{c}\text { Mean } \\
\text { Square }\end{array}$ & F & Sig. \\
\hline $\begin{array}{c}\text { Between } \\
\text { Groups }\end{array}$ & 2.851 & 1 & 1.425 & 5.080 & .006 \\
\hline Within Groups & 229.087 & 263 & .270 & & \\
\hline Total & 231.930 & 262 & & & \\
\hline
\end{tabular}

Table 4 shows the analysis for media literacy whereby there is a statistically significant difference at the $p<.05$ level in the score for the three majors on media literacy skills elements, $F(2,818)=5.09, p=.006$. Thus, the hypothesis is rejected. Post-hoc comparison using Tukey HSD test (see Table 5) indicated that the mean between TESOL, science and arts score revealed a significant difference.

Table 5. Post-hoc test using Tukey HSD for Media Literacy skills

\begin{tabular}{|c|c|c|c|c|}
\hline \multirow{2}{*}{ (I) Major } & (J) Major & Mean Difference (I-J) & Std. Error & Sig. \\
\hline \multirow{2}{*}{ TESOL } & SCIENCE & $.12048^{*}$ & .04331 & .016 \\
\cline { 2 - 5 } & ARTS & $.16758^{*}$ & .06149 & .017 \\
\hline \multirow{2}{*}{ SCIENCE } & TESOL & $-.12057^{*}$ & .04329 & .018 \\
\cline { 2 - 5 } & SRTD & .04700 & .05517 & .669 \\
\hline \multirow{2}{*}{ ARTS } & TESOL & $-.16766^{*}$ & .06154 & .017 \\
\cline { 2 - 5 } & SCIENCE & -.04711 & .05517 & .670 \\
\hline
\end{tabular}

\subsection{Comparison between the Information Literacy Skills among Trainee Teachers for Different Majors}

H01b: There is no significant difference between the information literacy skills possessed by the students for different majors in developing e-Portfolio.

The information literacy skills and different majors variables result showed that there was statistically no significant difference at $\mathrm{p}>.05$ level. Also, the score derived from three majors on information literacy: F (2, $818)=.897, \mathrm{p}=.408$ is shown in Table 6 . Thus, the hypothesis was not rejected. Levene's test (see Table 7) for homogeneity of variance was conducted and the significant value is $\mathrm{p}=.812>0.05$. Hence, the homogeneity of variance assumption is not violated, as shown in Table 8 . The posthoc test is not necessary since there was no significant difference for the three majors on information literacy variable.

The information literacy skills and different major variables, there was statistically no significant difference at the $p>.05$ level in the score for the three majors on information literacy: $\mathrm{F}(2,818)=.897, \mathrm{p}=.408$ as shown in Table 6 . Thus, the hypothesis was not rejected. Levene's test (see Table 7) for homogeneity of variance was conducted and the significant value is $\mathrm{p}=.812>0.05$. Hence, the homogeneity of variance assumption is not violated. The posthoc test is not necessary since there was no significant difference for the three majors on information literacy variable.

Table 6. Descriptive Table for Information Literacy skills

\begin{tabular}{|c|c|c|c|c|c|c|c|c|}
\hline & \multirow{2}{*}{$\mathrm{N}$} & Mean & \multirow{2}{*}{ Std. Deviation } & \multirow{2}{*}{ Std. Error } & \multicolumn{2}{|c|}{$95 \%$ Confidence Interval for Mean } & \multirow{2}{*}{ Min } & \multirow{2}{*}{ Max } \\
\cline { 6 - 8 } & & & & & Lower Boundary & Upper Boundary & & \\
\hline TESOL & 78 & 4.3803 & .54354 & .03716 & 4.3070 & 4.4535 & 2.87 & 5.88 \\
\hline Arts & 144 & 4.3299 & .57268 & .02577 & 4.2791 & 4.3805 & 2.17 & 6.00 \\
\hline Science & 43 & 4.3011 & .55629 & .05233 & 4.1969 & 4.4048 & 3.28 & 6.00 \\
\hline Total & 265 & 4.3390 & .56292 & .01965 & 4.3004 & 4.3777 & 2.19 & 6.00 \\
\hline
\end{tabular}

Table 7. Test of Homogeneity of Variances for Information Literacy Skills

\begin{tabular}{|c|c|c|c|}
\hline $\begin{array}{l}\text { Levene's } \\
\text { Statistics }\end{array}$ & df1 & df2 & Sig. \\
\hline .209 & 1 & 263 & .812 \\
\hline
\end{tabular}

Table 8. ANOVA Table Variable Information Literacy skills

\begin{tabular}{|c|c|c|c|c|c|}
\hline & Sum of Squares & df & Mean Square & F & Sig. \\
\hline Between Groups & .568 & 1 & .284 & .897 & .408 \\
\hline Within Groups & 259.274 & 263 & .317 & & \\
\hline Total & 259.843 & 264 & & & \\
\hline
\end{tabular}




\subsection{Comparison between the ICT Skills among Trainee Teachers in Different Majors}

$\mathrm{H}_{1 \mathrm{cc}}$ : There is no significant difference between the information and communication technology skills possessed by the students for different majors in developing e-Portfolio.

The result in Table 9 shows Levene's test for homogeneity of variance, which was conducted on information and communication technology skills. The significant value was $\mathrm{p}=.458>0.05$. Thus, the homogeneity of variance assumption is not violated. The null hypothesis for homogeneity assumption is retained and it shows that there is no significant difference between the group's variances. (see Table 10). The results showed that information and communication technology (ICT) skills among trainee teachers are similar despite some disparities in majors.

Table 9. Test of Homogeneity of Variances on Information and Communication Technology Skills

\begin{tabular}{|c|c|c|c|}
\hline $\begin{array}{l}\text { Levene's } \\
\text { Statistics }\end{array}$ & df1 & df2 & Sig. \\
\hline .782 & 1 & 263 & .458 \\
\hline
\end{tabular}

Table 10. Descriptive Table for Information and Communication Technology Skill

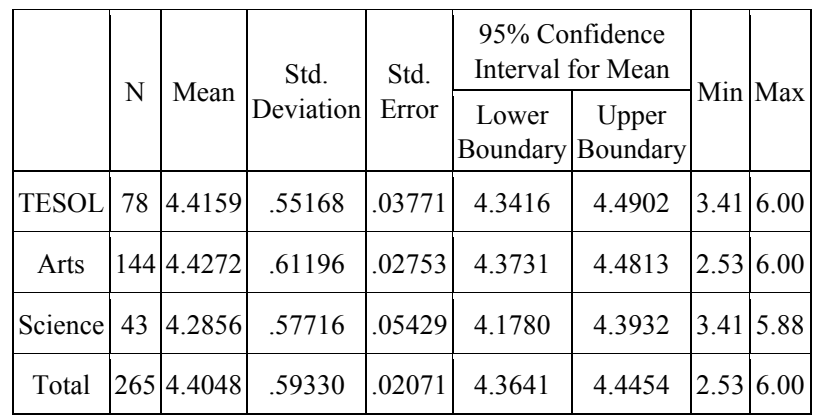

Information and communication technology skills with different major variables did not have a statistically significant difference at $\mathrm{p}>.05$ level. The score for the three majors on information and communication technology skills are: $F(2,818)=2.681, \mathrm{p}=.068$ (see Table 11). Thus, $\mathrm{H}_{1 \mathrm{cc}}$ was not rejected. The post-hoc test is not necessary as there was no significant difference in the information literacy variable for the three majors. There was no significant difference between the three majors on information and communication technology skills.

Table 11. ANOVA Table for Information and Communication Technology Skills

\begin{tabular}{|c|c|c|c|c|c|}
\hline & $\begin{array}{c}\text { Sum of } \\
\text { Squares }\end{array}$ & df & $\begin{array}{c}\text { Mean } \\
\text { Square }\end{array}$ & F & Sig. \\
\hline $\begin{array}{c}\text { Between } \\
\text { Groups }\end{array}$ & 1.879 & 1 & .940 & 2.681 & 0.68 \\
\hline Within Groups & 2.86 .760 & 263 & .351 & & \\
\hline Total & 288.639 & 264 & & & \\
\hline
\end{tabular}

\section{Findings}

This study explored the IMT skills of trainee teachers with three main elements and every element consist of sub-elements as follows:

(a) media literacy skills

(i) analyse media

(ii) create media products,

(b) information literacy skills

(i) access and evaluate information

(ii) use and manage information,

(c) information communication technology

(i) apply technology effectively.

The highest mean score for IMT skills was recorded on the media analysis element. However, the lowest mean score emerged from creating media products element. This result shows that trainee teachers have higher skills in media analysis than other IMT abilities. The earlier part of the course in this study involved trainee teachers' interaction with various technology-based apps. During this phase, the students' task was to analyse various apps and tools. This is the reason why the media analysis component has a higher score compared to other IMT skills.

The study findings indicate that there is a significant difference between teaching English to speakers of other languages (TESOL), science and arts trainee teachers on media literacy skills. The difference was shown between TESOL, science and arts trainee teachers with TESOL having the highest mean score. However, science and arts trainee teachers did not differ significantly from each other. Also, the findings show that there is no significant difference between the sub media literacy skills, which consist of media analysis and create media product elements. The reason for the no significant difference on media literacy is due to trainee teacher's exposure to multimedia contents activities.

In addition, there are no other courses that integrate ICT creating and developing skills in their courses. Hence, this research revealed that trainee teachers have inadequate time to explore teaching materials in this course. These research findings are in parallel with Rizal, Setiawan \& Rusdiana [27] study, which showed that the trainee teachers are presented with assignments only in Microsoft word with PowerPoint format. However, both formats do not help trainee teachers in creativity and multimedia development.

This study findings show that students in TESOL possess higher media literacy skills than the other two majors in this research. This finding emanates from TESOL students' minor module in multimedia, which is offered at a very early stage in the university.

\section{Discussion}

This study began with the need to explore trainee 
teachers' information media and technology (IMT) skills based on a $21^{\text {st }}$ century framework. This is necessary to prepare trainee teachers for employment after graduation in Malaysia. The IMT skills were required to produce an e-Portfolio in an ICT course. Also, the respondents were required to respond to questionnaire items with a 6-week ultimatum after producing an e-Portfolio. This study was conducted with the intention of embedding the $21^{\text {st }}$ century skills into trainee teachers for future employers. In developing an e-Portfolio the trainee teachers were expected to use IMT skills to create a comprehensive e-Portfolio as well as the embedding element of creativity to attract future employer. Advancement in ICT not only reshaped the traditional settings of learning. ICT progress monitors student imagination and the application of various pedagogical approaches [28]. Thus, this study was conducted to fill three gaps in literature such as (a) employment skills that concern career path of graduates (b) research on $21^{\text {st }}$ century IMT skills specifically for trainee teachers and (c) pedagogical paradigm shift in learning due to changes in $21^{\text {st }}$ century.

This research contributes to two main issues, which are (a) the body of knowledge of $21^{\text {st }}$ century skills and (b) trainee teachers IMT skills. The main elements for the IMT skills according to P21 are (a) media literacy skills (b) information literacy skills with (c) information and communication technology. This study contributes to the body of knowledge in $21^{\text {st }}$ century skills and extends the pedagogical learning paradigm. Also, this research explains the new paradigm of learning in the $21^{\text {st }}$ century. The framework on partnership in $21^{\text {st }}$ century skills contributes to the exploration of trainee teacher's workforce in this fourth industrial revolution.

Integrating IMT literacy into the curriculum has shown that TESOL trainee teachers have significant media literacy skills compared to students of science and the arts. When guiding trainee teachers from different departments, the instructor did not resort to any specific methods. The instructor also employed a holistic approach in facilitating the development of the e-portfolio. However, the outcome needs to be further explored in order to know why there is a significant difference between majors.

There is an emergence used of technologies in the workplace and educational establishment for managing media resources [7]. The IMT skills entail critical evaluation of information and media contents, which must be given more attention in this $21^{\text {st }}$ century. Hence, the additional focus must be geared towards developing teacher's knowledge, ability, media, and technology.

\section{Conclusions}

This study investigated the IMT skills possessed by trainee teachers in a Malaysian university. This research is necessary to explore trainee teachers' $21^{\text {st }}$ century skills for the workplace environment. However, this study focused only on the IMT abilities proposed by the partnership of $21^{\text {st }}$ century skills (P21) framework. Thus, this study recommends the use of other frameworks to understand trainee teachers' digital literacy for Education 4.0. This study contributes to the impact of $21^{\text {st }}$ century skills research in Malaysia. Previously in Malaysia, graduates in the educational field used to secure employment easily after graduation. However, securing teaching jobs for graduates has become difficult nowadays. Thus, higher educational establishments must consider the urgency in providing adequate $21^{\text {st }}$ century skills for trainee teachers to empower graduates in securing jobs after graduation in this technologically advanced era.

\section{Acknowledgments}

This research is funded by Universiti Sains Malaysia Bridging Grant 2018 (304.PGURU.6316207).

\section{REFERENCES}

[1] Triki, N. M. M. (2010). A critical assessment of the technical and vocational education and training programme for the Libyan chemical industry. Edinburgh Napier University. Retrieved from http://researchrepository.napier.ac.uk/4280/. 2010

[2] Janet, B. B., Kimberly, A. G., \& Ken, K.. Up to the Challenge: The Role of Career and Technical Education and 21st Century Skills in College and Career Readiness. U. S.: Career Technical Education Consortium and Partnership for 21st Century Skills. 2010

[3] The Partnership for 21st Century Skills. IMT skills. Retrieved June 16, 2018, from http://www.p21.org/about-us /p21-framework/266-life-and-career-skills. 2018

[4] Trilling, B., \& Fadel, C. 21st Century Skills: Learning for Life in Our Times. Jossey-Bass. John Wiley \& Sons. Retrieved from http://www.hrdcentral.com/21st-century-ski lls-learning-for-life-in-our-times.html/. 2009

[5] Partnership for 21st Century. 21st Century Skills, Education \& Competitiveness: A Resource and Policy Guide. Retrieved from http://wieettassessment.pbworks.com/f/21st CenturySkillsEducationandCompetitivenessGuide.pdf 2008

[6] Lemke, Cheryl. enGauge 21st Century Skills: Digital Literacies for a Digital Age. 2002

[7] Kivunja, C. Do You Want Your Students to Be Job-Ready with 21st Century Skills? Change Pedagogies: A Pedagogical Paradigm Shift from Vygotskyian Social Constructivism to Critical Thinking, Problem Solving and Siemens' Digital Connectivism. International Journal of Higher Education, 3(3), 81-91. doi:10.5430/ijhe.v3n3p81. 2014

[8] Pitts, W., \& Lehner-Quam, A. Engaging the Framework for Information Literacy for Higher Education as a Lens for 
Assessment in an e-Portfolio Social Pedagogy Ecosystem for Science Teacher Education. International Journal of e-Portfolio, 9(1), 29-44. 2019

[9] Lorenzo, G. \& Ittelson, J. An overview of e-portfolios. Educause Learning Initiative, ELI Paper 1 [online]. Available:

http://net.educause.edu/ir/library/pdf/ELI3001.pdf. 2005

[10] Douglas, C., E-portfolios: The Cornerstone of Personal Learning, Retrieved July 2019 from: http://educationalelear ningresources.yolasite.com/resources/Desire2Learn_whitep aper_ePortfolio_cornerstone.pdf. 2012

[11] Ciesielkiewicz, M. The use of e-portfolios in higher education: From the students' perspective. Issues in Educational Research, 29(3), 649-667.2019

[12] Bolliger, D. U. \& Shepherd, C. E. Student perceptions of e-Portfolio integration in online courses. Distance Education, 31(3), 295-314. https://doi.org/10.1080/01587919.2010.513 955. 2010

[13] Archer, W., Davison, J., Brown, R., \& Herrmann, K. Graduate employability: the views of employers. Council for Industry and Higher Education. Retrieved January2018 from

https://scholar.google.com/scholar?hl=en\&q=Graduate+em ployability $\% 3 \mathrm{~A}+\mathrm{The}$

+views + of + employers\&btnG $=\&$ as_sdt $=1 \% 2 \mathrm{C} 5 \&$ as_sdtp $=$ \#1. 2008

[14] Daniels, J., \& Brooker, J. Student identity development in higher education: implications for graduate attributes and work-readiness. Educational Research, 56(1), 65-76. doi:10.1080/00131881.2013.874157. 2014

[15] Fong, L. L., Sidhu, G. K., \& Fook, C. Y. Exploring 21st Century Skills among Postgraduates in Malaysia. Procedia Social and Behavioral Sciences, 123, 130-138. doi:10.1016/j.sbspro.2014.01.1406. 2014

[16] Triki, N., Gupta, N., \& Rafik, T. A critical evaluation into the role of the Libyan technical and vocational education in providing the skills required by the national manufacturing industry. EDULEARN12 Proceedings, 5582-5590. 2012

[17] Bybee, R. W., \& Fuchs, B. Preparing the 21st-century workforce: A new reform in science and technology education. Journal of Research in Science Teaching, 43(4), 349-352. 2006

[18] Ministry of Higher Education. The National Higher
Education Strategic Plan. Percetakan Nasional Berhad, Kuala Lumpur, 2012. doi:10.1037/e566372006-001. 2012

[19] Osman, K., Soh, T. M. T., \& Arsad, N. M. Development and validation of the Malaysian 21st-century skills instrument (M-21CSI) for science students. Procedia Social and Behavioral Sciences, 9, 599-603. doi:10.1016/j.sbspro.201 0.12.204. 2010

[20] Philomina, M. J; \& Amutha, Information and communication technology awareness among teacher educators, International Journal of Information and Education Technology. Vol. 6, Iss. 8, (Aug 2016): 26-9. 2016

[21] Zikre, N. M., \& Eu, L. K. Malaysian mathematics teachers' beliefs about the nature of teaching and learning. MOJES: Malaysian Online Journal of Educational Sciences, 4(1), 21-29. 2018

[22] Greenhill, V, \& Petroe S. 21St century knowledge and skills in educator preparation. Education (p. 30). Retrieved from http://www. p21.org. 2010

[23] Koehler, M. J., \& Mishra, P. Introducing TPACK. In J. A. Colbert, K. E. Boyd, K. A. Clark, S. Guan, J. B. Harris, M. A. Kelly, \&A. D. Thompson (Eds.), Handbook of technological pedagogical content knowledge for educators (pp. 1-28). New York: Routledge. 2008

[24] Littrell, A.B., Zagumny, M.J. \& Zagumny, L.L. Contextual and Psychological Predictors of Instructional Quarterly, 29(2), 37-47. Retrieved January 24, 2020, from https://www.learntechlib.org/p/63644/. 2005

[25] Samy, Naresh Kumar and Che Rose, Raduan and Alby, Jeffrey Lawrence D'Silva. Teachers' readiness to use technology in the classroom: an empirical study. European Journal of Scientific Research, 21 (4). pp. 603-616. ISSN 1450-216X; ESSN: 1450-202X. 2008

[26] Saveedra, V.D. Opfer, Learning 21st-century skills requires 21st-century teaching, Phi Delta Kappan, 94 (2). pp. 8-13. 2012

[27] Rizal, R., Setiawan, W., \& Rusdiana, D. Digital literacy of pre-service science teacher. In Journal of Physics: Conference Series (Vol. 1157, No. 2, p. 022058). IOP Publishing. 2019

[28] Serdyukov, P. Innovation in education: What works, what doesn't, and what to do about it?. J Res Innovative Teach Learn 10 (1), 4-33. 2017 